\title{
THE ROLE OF IDENTIFYING AND MANAGING CULTURAL VALUES IN RURAL DEVELOPMENT
}

Mateja Šmid Hribar, Špela Ledinek Lozej

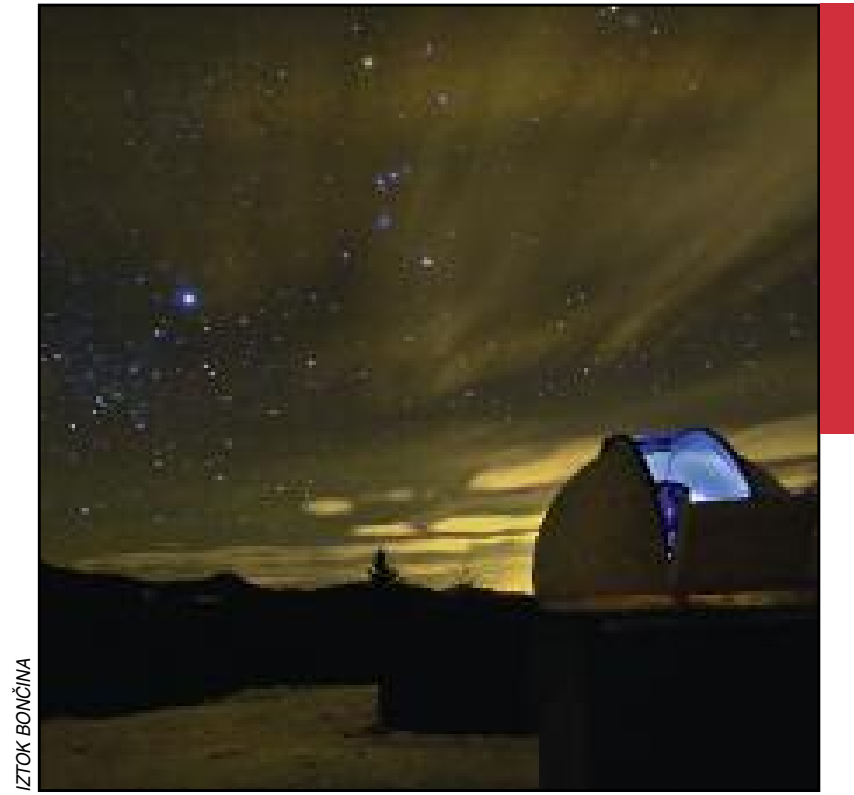

At Astronomical Observatory Javornik amateur astronomers and visitors can observe the dark sky with their naked eye or with binoculars and telescopes of different sizes. 


\section{The role of identifying and managing cultural values in rural development}

DOI: $10.3986 / A G S 53402$

UDC: $316.75: 711.3(497.4)$

COBISS: 1.01

ABSTRACT: Cultural and natural elements contribute to the development of rural areas. Identifying and evaluating development aspects and the interconnection of cultural values and local stakeholders are key to managing cultural values. This article defines cultural values with development potential by studying the relevant research literature and legislation, carrying out field studies in the Idrija countryside, and using an online questionnaire to evaluate development aspects.

KEY WORDS: geography, culture, heritage, cultural values, countryside, development, Idrija, Črni Vrh, Slovenia, SY_CULTour

The article was submitted for publication on December 20, 2012.

ADDRESSES:

Mateja Šmid Hribar, M. Sc.

Anton Melik Geographical Institute

Research Center of the Slovenian Academy of Sciences and Arts

Gosposka ulica 13, SI - 1000 Ljubljana

E-mail: mateja.smid@zrc-sazu.si

Špela Ledinek Lozej, Ph. D.

Institute of Slovenian Ethnology

Research Center of the Slovenian Academy of Sciences and Arts

Nova Gorica Research Station

Delpinova 12, SI - 5000 Nova Gorica

E-mail: spela.ledinek@zrc-sazu.si

\section{Contents}

1 Introduction $\quad 373$

2 Methods 373

Outlining the development of cultural
heritage protection

$4 \quad$ Results and discussion 374

5 Conclusion 377

6 References $\quad 377$ 


\section{Introduction}

A rich cultural and natural heritage offers a development opportunity in the countryside, in which its effective management and the inclusion of local stakeholders are of key importance. This article is based on the research carried out as part of the European project SY_CULTour (Synergy of Culture and Tourism: Utilisation of Cultural Potentials in Less Favoured Rural Regions), which proceeded from the premise that various cultural values must be connected and combined into a comprehensive (tourist) product managed by its stakeholders. A selection and description of cultural values and various good practice examples of management can help design these types of products. Field research was carried out in the Idrija countryside, but the results and findings obtained in other pilot areas of the project were taken into account in conducting the analysis and drawing the final conclusions. In addition to cultural values and good practice examples from the pilot area of the leading project partner (i.e., the Idrija countryside), the analysis also included cultural values and good practice examples from other partner pilot areas, such as Jesenice and the Central Sava region (Slovenia), Strelcha (Bulgaria), Crete and Mt. Pelion (Greece), Aquila and Trentino (Italy), the central Danube region (Hungary), and the Sombor and Apatin areas (Vojvodina, Serbia).

The purpose of this article is to highlight the role of cultural values in rural development and draw attention to the role of local stakeholders in identifying and managing cultural values.

\section{Methods}

We used the following methods:

- Literature review;

- Review of legislation;

- Fieldwork in the Municipality of Idrija: an overview of cultural heritage and good practice examples of managing cultural heritage; and

- Carrying out workshops with the local people, in which the participatory method was used.

In the first step of identifying cultural values with development potential, we studied the available research literature, reviewed the immovable cultural heritage register, and examined the good practice examples of managing cultural heritage in the pilot areas. In the second step, from June to November 2011, we selected and described those units of cultural heritage in the pilot area that we identified as having a certain degree of development potential. We focused on the registered cultural heritage objects in the Municipality of Idrija, leaving aside the heritage in the towns of Idrija and Spodnja Idrija. We then further expanded our basic selection of cultural values based on observation, non-structured interviews with various local stakeholders, and a review of professional literature (SY_CULTour Cultural Values 2012). In addition, we selected and described two good practice examples of managing cultural values based on a professional literature review and fieldwork conducted in September 2011 (SY_CULTour Good Practice 2012). The participatory method used for identifying cultural values and the subsequent planning of their management, which was addressed at workshops carried out with local stakeholders between November 2012 and March 2013 in Črni Vrh, significantly added to the selection of cultural values. Based on the findings obtained, we developed an online questionnaire to assess the scale and aspects of the development potential of a specific cultural value.

\section{Outlining the development of cultural heritage protection}

The first attempts to evaluate cultural elements in Europe can be traced back to the Renaissance, and the first efforts to protect, preserve, and restore them back to the eighteenth century. The first institutionalized efforts to protect natural and cultural monuments reach back to nineteenth-century processes of raising nation's awareness (Anko 1988; Šmid Hribar et al. 2009). The first international document regulating the relationship towards cultural heritage was the Athens Charter (1931). The protection and preservation of remnants from the past strengthened after the Second World War with the establishment of the United Nations (1945), the UN Educational, Scientific, and Cultural Organization (UNESCO 1946), and the organizations under them, such as the International Council of Museums (ICOM 1946), the International Center 
for the Study of the Preservation and Restoration of Cultural Property (ICCROM 1956), and in 1965 the International Council on Monuments and Sites (Jokilehto 2005, 287 and 288). In addition to UNESCO, the 1949 establishment of the Council of Europe and the 1963 founding of the nongovernmental organization Europa Nostra are also associated with identifying cultural values (Delak Koželj 2009, 27-31; Fakin Bajec 2011).

The term »cultural heritage « was introduced into European discourse and consolidated in the second half of the twentieth century by the international institutions listed above, led by UNESCO, and especially by the 1972 Convention on the Protection of World Cultural and Natural Heritage. The Convention on the Protection of Intangible Heritage adopted in 2003 was expanded to also include intangible heritage, which it defined as the practices, presentations, expressions, knowledge, skills, and related tools, objects, products, and cultural spaces that communities, groups, and sometimes individuals recognize as part of their cultural heritage (Convention ... 2003). According to this convention, cultural heritage was no longer merely a corpus of material objects, but it also highlighted the significance of non-material elements, especially the subjective judgment of communities, groups, and individuals, and their relationship to cultural elements identified as cultural heritage. This is not merely "an exceptional universal value « selected by various professionals (Jokilehto 2006), but it can also be identified by various groups, communities, and even individuals. The concept of heritage has been (re)formed in line with people's changing relationships, needs, and demands (Loulanski and Loulanski 2013).

In addition to protection and preservation, institutions and researchers involved in spatial planning and tourism have also highlighted regional and economic development when dealing with cultural elements or, in other words, their development potential (Greffe, Pflieger and Noya 2005). This was also taken into account in the extensive development goals of the SY-CULTour project, which looked for synergy between culture and tourism, in which culture was understood in the widest sense possible - a wide range of achievements and values of human society. Due to methodological, semantic, and political reasons, we used the term »cultural values« instead of the generally more common term »cultural heritage. «The methodological reason refers to the participatory methodology, which we used to look for those cultural elements that individuals or a specific group of people identify as important and valuable. The semantic reason proceeds from the etymology of the terms »heritage « and »value; « heritage is something that was or can be inherited, whereas value originates in the verb "to value, « which refers to defining, establishing, ascribing, and acknowledging value, importance, and quality, and thus addresses the relationship between a group or an individual and a specific cultural element. The last reason was political implications of cultural heritage that are constructed and regulated by institutions or groups and individuals empowered by cultural capital, and are thus also a means of operationalizing cultural policy. In the Guidelines for Managing Cultural Values in rural areas, prepared and tested as part of SY_CULTour, the preservation of cultural heritage and development are not alternatives, but a mutually interconnected and balanced choice.

\section{Results and discussion}

As part of SY_CULTour, we first and foremost looked for cultural elements with development potential. In this, development was understood in line with the definition of sustainable development, which strives for the needs of today's generations not to burden the realization of the needs of future generations (Report ... 1987; A Sustainable Europe ... 2001). Initially, the concept of sustainable development referred to economics, ecology, and society. However, in 2002 Agenda 21 for Culture was adopted in Porto Alegre, which added a fourth, cultural pillar of sustainable development to the economic, environmental, and social pillars (Agenda 21 ... 2002). Based on this, an online questionnaire was developed in order to help us identify the scope and aspects of the development potential of individual cultural values. The evaluation included the level of identifying and managing cultural values, the distribution at the local and international levels, the preservation level, the amount of required investment, the integration with other cultural values, the usage, mobilization potential, current and potential management stakeholders, and target groups. The social potential of a specific cultural value was influenced by the number of those participating in its management and any integration, identification, representational, and communicational potentials. The ecological aspect of the development potential of cultural values is evident from the ratio between positive and negative impact on the environment and nature, and the cultural aspect from whether 


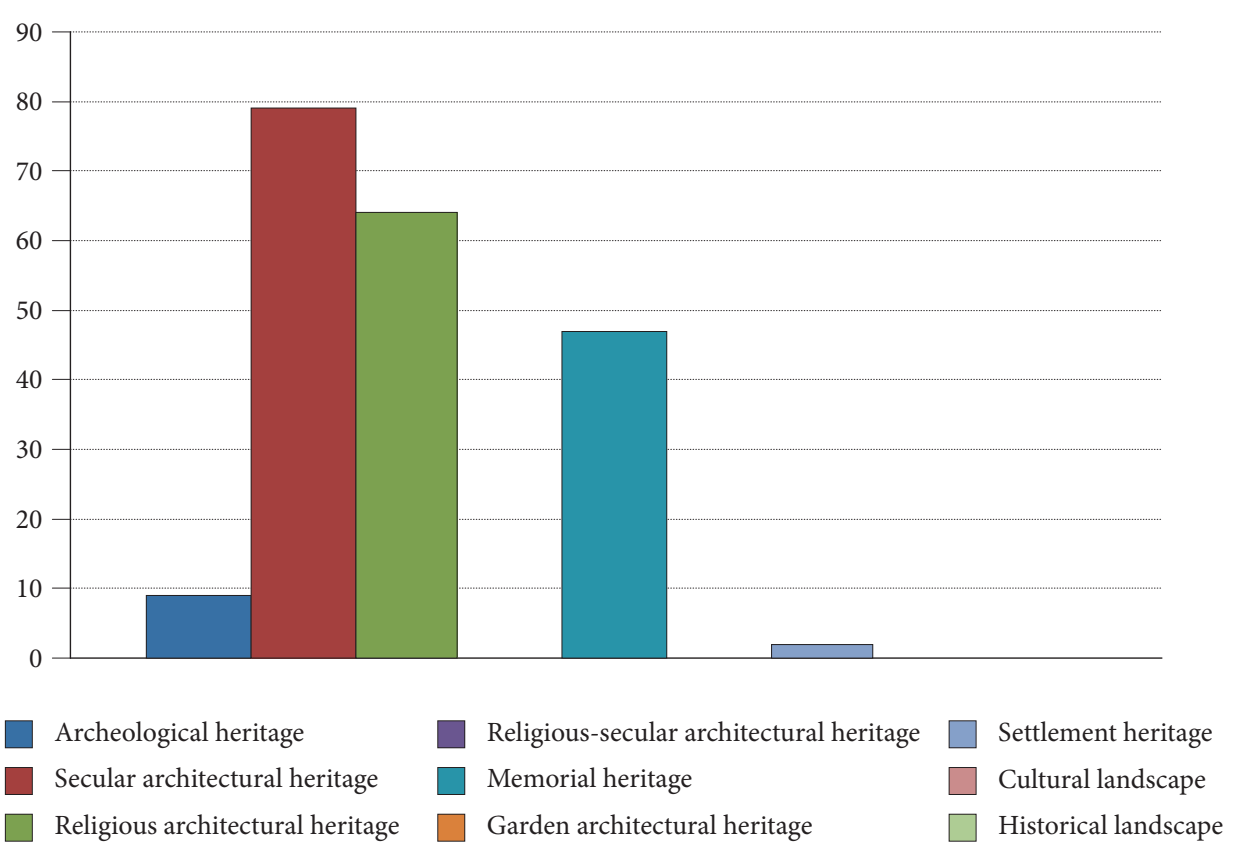

Figure 1: Heritage units in the Idrija countryside recorded in the Immovable Cultural Heritage Register (source: Immovable Cultural Heritage Register).

the assessed element enables creative and intellectual experience and practices. In the fall of 2012 we tested 22 cultural values, in which the first results showed that the majority of the values assessed primarily have an economic aspect, followed by social and spiritual aspects, and to a smaller extent also an ecological aspect of development potential (Evaluation ... 2012).

Based on defining the aspects of the development potential and selecting cultural values and good practice examples, we developed a comprehensive definition of cultural values with development potential: »Cultural values are various tangible and intangible elements and individual natural elements of cultural significance and local origin that are identified by the stakeholders and have economic, social, ecological, or cultural development potential. The development importance of a specific cultural value co-depends on the utility, compatibility, and scope of development potential (Šmid Hribar et al. 2012, 19).

In the pilot area of the Idrija countryside, we established both overlaps and deviations between the cultural heritage documented by the Institute for the Protection of Cultural Heritage of Slovenia and the cultural values identified in situ among the bearers, creators, and stakeholders of cultural elements. A review of the Immovable Cultural Heritage Register (2012) showed that secular architectural heritage predominates in the Idrija countryside ( 79 structures), followed by religious ( 64 structures), memorial (47 structures), archeological (nine structures), and settlement heritage (two structures; Figure 1). Other types of immovable cultural heritage were not identified in the pilot area.

Later inventory of cultural values in the Idrija countryside, and especially the workshops carried out in Črni Vrh, yielded a different set of cultural elements. At the workshop, participants were asked what values they would highlight in their local environment. They therefore listed and classified the values that they thought had development potential. Observing the night sky at the Javornik observatory scored the highest, in addition to the preservation of flax production and processing, Cross-country Trnovski marathon, the Matuckar Path, and the narrow gauge railway line (Table 1).

In addition to the differences between the registered cultural heritage and the cultural values identified by the participants, the workshops in Črni Vrh and general fieldwork also revealed a difference between the cultural elements identified in the town of Idrija and recognized as cultural heritage and the signifi- 
Table 1: Cultural values highlighted and assessed at the SY_CULTour workshop on the management of cultural values carried out on 6 November 2012 in Črni Vrh.

\begin{tabular}{lc}
\hline Cultural value & Score \\
\hline Observing the night sky at the Javornik observatory & 10 \\
Flax production and processing & 8 \\
Cross-country Trnovski marathon & 8 \\
Matuckar Path & 7 \\
Narrow gauge railway line in connection with hiking & 7 \\
Collection of First World War items & 5 \\
Making a charcoal pile & 5 \\
Windmill & 5 \\
Dugouts and bunkers & 4 \\
Restoration of Idrija lace & 4 \\
Via Alpina hiking trail & 3 \\
Tominc House & 2 \\
Renovation of a blacksmith's workshop & 2 \\
Tower on Špičasti vrh & 2 \\
Military cemetery in Črni Vrh & 2 \\
Singing activity & 1 \\
Teamsters & 1 \\
Lime kilns & 1 \\
Ivanjšek linden tree & 1 \\
Pond & 1 \\
Flax-drying device & 1 \\
Homemade baked goods & 1 \\
Pond & 0 \\
\hline
\end{tabular}

Figure 2: Visitors observe remains of a tunel of fomer narrow gauge railway known as »Feldban« constructed during the 1st WW in 1917.

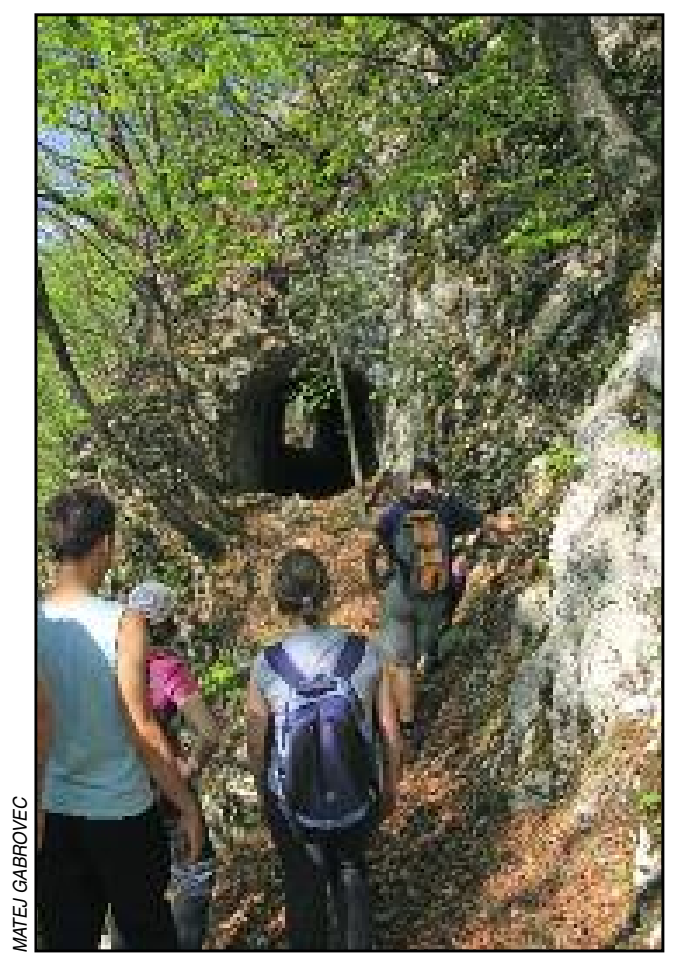


cantly fewer cultural elements identified and recognized in the Idrija countryside. Due to the long years of efforts to include Idrija on the UNESCO World Heritage List, the town of Idrija - together with its municipal administration, town museum, development agency, Geopark, and the Idrija Heritage Center - largely focused on the mercury mine heritage and the related technological heritage (shafts, mining machinery, headraces, and logging sluices), handicrafts (lace-making), and culinary heritage. The Geopark established in 2010 was a formal attempt to bridge the gap between identifying and promoting urban and rural cultural elements and displaying a comprehensive attitude towards cultural and natural environmental elements, whereas, in the operational sense, this has been carried out through the Idrija-Cerkno Development Agency. Nonetheless, a hegemony of urban heritage over rural heritage can be observed in the Idrija region; for instance, this can be perceived from the omnipresent availability of Idrija filled pasta (known as žlikrofi), which in the past were merely a somewhat refined miners' dish. This hegemony results partly from the actual socio-historical circumstances and partly from the modern positioning of (economic, social, and cultural) capital.

The set of cultural values identified in Črni Vrh and the surrounding area is a step towards connecting the city and countryside into a single development opportunity with a common sustainable selection of tourism services and social-cultural infrastructure. In this regard, we were especially interested in where the breakthrough occurs, when one or several cultural values become attractive to the market and began to affect the area's development. Bigaran et al. (2013) highlight the fact that, in order to achieve success, the stakeholders' ability to use and enhance local resources is more important than the topic itself. The analysis of good practices of managing cultural values showed that a successful good practice demands the following: 1) active participation of local stakeholders, 2) political will that affects economic and other initiatives, and 3) enterprising marketing and promotion. This calls for considering the ways in which the identified cultural values can be connected into a comprehensive marketable story or product that will bring development to rural areas. In this, long-term physical, social, economic, cultural, and environmental benefits for the local community should be taken into account rather than seeking short-term gains (Loulanski \& Loulanski 2013).

\section{Conclusion}

Suitably recognized and managed cultural values can significantly influence the sustainable development of rural areas, in which not only economic aspects are important, but also ecological, social, and cultural aspects. Because not all cultural values have potential for development, an online questionnaire was developed in order to facilitate the identification of development aspects. The first results of the values assessed showed the predominance of economic potential, followed by social and cultural potentials, and, to a smaller extent, ecological potential. The activation of development potential demands suitable management of cultural values with identified potential, in which the participation of local stakeholders and the interconnection of cultural values into a comprehensive product are especially important. Due to their development opportunities, good practice examples of managing cultural values can positively influence young people's decision to stay in the countryside, help transfer various knowledge and skills between generations (including those related to effectively connecting the stakeholders, and the promotion and marketing of local products and services), and ultimately they can also be the source of inspiration and an opportunity to transfer these skills to other areas at both the national and international levels. The interconnection of various cultural values and cooperation between various stakeholders that can effectively obtain, activate, and enhance local resources (both financial and human) are key to effective sustainable management that can gradually develop into a good practice example, such as the case of organizing and promoting the Idrija Lace Festival.

\section{References}

Agenda 21 for Culture. 2002: Internet: http://www.agenda21culture.net/index.php?option=com_content\&view=article\&id=44\&I (7.11.2012).

Anko, B. 1988: Varstvo naravne in kulturne dediščine v gozdarski teoriji. Varstvo naravne in kulturne dediščine $\mathrm{v}$ gozdu in gozdarstvu. Ljubljana. 
A Sustainable Europe for Better Worlds: A European Union Strategy for Sustainable Development (Commission's Proposal to the Gothenburg Strategy). 2001: Internet: http://eurlex.europa.eu/LexUriServ/ LexUriServ.do?uri=COM:2001:0264:FIN:EN:PDF (13.11.2012).

Athens Charter for the Restoration of Historic Monuments. 1931: Internet: http://www.icomos.org/athens_charter.html (25.10.2011).

Bigaran, F., Mazzola, A., Stefani, A. 2013: Enhancing territorial capital for developing mountain areas: the example of Trentino and its use of medicinal and aromatic plants. Acta Geographica Slovenica 53-2. Ljubljana. DOI 10.3986/AGS53403

Convention Concerning the Protection of the World Cultural and Natural Heritage. 1972: Internet: http://whc.unesco.org/archive/convention-en.pdf (4.11.2012).

Convention for the Safeguarding of the Intangible Cultural Heritage. 2003: Internet: http://unesdoc.unesco.org/images/0013/001325/132540e.pdf (4.11.2012).

Delak Koželj, Z. 2009: Etnologija in varstvo naravne in kulturne dediščine. Ljubljana.

Evaluation of Your Cultural Value with Regard to its Developmental Potential. 2012. Internet: http://www.sycultour.eu/vprasalnik (13.11.2012).

Fakin Bajec, J. 2011: Procesi ustvarjanja kulturne dediščine: Kraševci med tradicijo in izzivi sodobne družbe. Ljubljana.

Greffe, X., Pflieger, S., Noya A. 2005: Cultura e sviluppo locale: organizzazione per la cooperazione e lo sviluppo economico. Paris, Rovereto.

Jokilehto, J. 2005: A History of Architectural Conservation. Oxford.

Jokilehto, J. 2006: World Heritage: Defining the outstanding universal value. City \& Time 2-2/1. Internet: http://www.ceci-br.org/novo/revista/docs2006/CT-2006-45.pdf (20.11.2012).

Loulanski, V., Loulanski T. 2014: The Heritization of Bulgarian Rose. Acta Geographica Slovenica 54 (1). DOI 10.3986/AGS54408

Report of the World Commission on Environment and Development. 1987: Internet: http://www.un.org/documents/ga/res/42/ares42-187.htm (7.11.2012).

Register nepremične kulturne dediščine. 2012: Internet: http://rkd.situla.org/ (13.11.2012).

SY_CULTour Cultural Values. 2012: Internet: http://www.sycultour.eu/cultural-values (15.11.2012).

SY_CULTour Good Practices. 2012: Internet: http://www.sycultour.eu/good-practices-1 (15. 11.2012).

Šmid Hribar, M., Ledinek Lozej, Š., Nared, J., Trenkova, L. 2012: Joint Survey of Cultural Values. Internet: http://www.sycultour.eu/documents/joint-survey-of-cultural-values-1 (15.11.2012).

Šmid Hribar, M., Petejan, S., Šolar, R. 2009: Prost dostop do slovenske e-dediščine in njena vloga pri izgradnji nacionalne identitete. Razvojni izzivi Slovenije. Ljubljana. 